\title{
Economic and racial inequalities in the prenatal care of pregnant teenagers in Brazil, 2011-2012
}

André Henrique do Vale de Almeida 1

Dhttps://orcid.org/0000-0003-4949-2192

Silvana Granado Nogueira da Gama 2

D https://orcid.org/0000-0002-9200-0387

Maria Conceição Oliveira Costa 3

https://orcid.org/0000-0001-6695-7268

Elaine Fernandes Viellas 4

https://orcid.org/0000-0001-5259-8102

Katrini Guidolini Martinelli 5

https://orcid.org/0000-0003-0894-3241

Maria do Carmo Leal 6

https://orcid.org/0000-0001-5694-5765

\footnotetext{
1,3 Departamento de Saúde. Universidade Estadual de Feira de Santana. Av. Transnordestina, s.n. Campus Universitário - Módulo VI. Novo Horizonte. Feira de Santana, BA, Brasil. CEP: 44.031-460. E-mail: almeida_ahv@hotmail.com

2,4-6 Departamento de Epidemiologia e Métodos Quantitativos em Saúde. Escola Nacional de Saúde Pública. Fundação Oswaldo Cruz. Rio de Janeiro, RJ, Brasil.
}

\begin{abstract}
Objectives: to analyze the prenatal care of pregnant teenagers interviewed in the postpartum period in Brazilian maternity hospitals, according to economic status and skin color.

Methods: data were obtained from the Birth in Brazil study, a national hospital-based survey in 2011 and 2012. Information was obtained from interviews with the postpartum women and from data collected from their prenatal cards. Multivariate logistic regression was used to verify whether maternal and prenatal care characteristics were associated with ina-dequate prenatal care.

Results: a total of 3,317 teenage mothers were interviewed in the postpartum period, $84.4 \%$ of whom had received inadequate prenatal care, with worse results for lower-income, lower-schooling, and multiparous teens. In the same way, it became evident the higher proportion of black teenagers and those from economic classes D/E among those who failed to receive routine laboratory tests, who received little orientation on the pregnancy, labor, and childbirth, and who were forced to go from one maternity hospital to another before being admitted to give birth.

Conclusions: strategies targeted to the most vulnerable pregnant teenagers should be implemented in order to achieve greater equality in teenagers' prenatal care, seeking to assure easier access, earlier initiation of care, and greater case-resolution capacity

Key words Prenatal care, Maternal and child health, Maternal and child health services, Teenage pregnancy
\end{abstract}

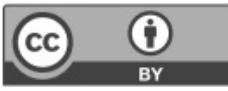




\section{Introduction}

Despite important progress in the coverage of prenatal care in Brazil, there are still many gaps, revealing economic and racial inequalities in access that affect the quality and effectiveness of care. ${ }^{1-3}$

A study of postpartum women in the city of Rio de Janeiro from 1999 to 2001 identified two major levels of discrimination (educational and racial) in the care provided by health services to pregnant women. ${ }^{4}$ Women's dissatisfaction with care was directly proportional to darker skin and less schooling. Black and mixed women and those with less education gave worse ratings to the care provided by health services during labor and childbirth.

There is a consensus concerning the relevance of prenatal care for achieving positive outcomes for both mother and child. This is especially important for pregnant teenagers, who tend to be socially underprivileged as a group. Studies in developed countries like the United States 5 as well as in SubSaharan Africa6 have identified disadvantages in the care for pregnant teenagers, who not only experience more difficulty in accessing health services, but also receive worse prenatal care. This is particularly true for teenagers with low schooling and low income.

Studies in Brazil indicate that pregnant teenagers tend to begin prenatal care later and attend fewer visits than older pregnant women, besides having fewer routine laboratory tests, $7-9$ revealing this age group's difficulties in receiving effective prenatal care. 9,10

New studies on socioeconomic and racial inequalities in the quality of prenatal and childbirth careare welcome.2,11 Considering that the effects of inadequate prenatal care are more severe in teenagers, ${ }^{8,12}$ this article aimed to gather evidence on the effect of socioeconomic and racial disparities in prenatal care for Brazilian teenagers.

\section{Methods}

The study's data are from the Birth in Brazil project, a national survey of postpartum women and their newborns, conducted from February 2011 to October 2012. Inclusion criteria were postpartum women who had given birth in hospital, where the outcome was live birth of any weight and gestational age or stillbirth with weight greater than $500 \mathrm{~g}$ or gestational age greater than 22 weeks. The sample was selected in three stages: the first consisted of hospitals with 500 or more births per year, stratified by Brazil's five major geographic regions, location (state capital versus city which is not capital), and type of hospital (private, public, and mixed); the second stage was according to the number of days of data collection (minimum of seven days in each hospital); and the third stage consisted of the postpartum women themselves. In each of the 66 sampled hospitals, 90 interviews were planned, totaling 23,894 women. More detailed information on the sample design is available in Vasconcellos et al. 13

The current study used data from the first phase of the study, based on face-to-face interviews with the postpartum women during their hospitalization, data obtained from the mothers' and newborns' medical charts, and mothers' prenatal cards. Detailed information on the data collection has been published elsewhere. 14

We analyzed the socioeconomic, demographic, behavioral, and reproductive characteristics of postpartum teenage women, as well as the prenatal care provided to them in the current pregnancy. Description of the group's characteristics included geographic region of residence (North, Northeast, South, Southeast, or Central-West of Brazil), age bracket (10-14 years versus 15-19 years), schooling (adequate for age versus inadequate), conjugal status (living with companion/husband versus without husband/companion), and parity (nulliparous, 1 previous birth, 2 or more previous births). The variable "adequacy of schooling for age" was calculated according to the expected years of schooling for the teenager's age.

Prenatal care was characterized according to the total number of prenatal visits, corrected for gestational age at the time of childbirth, early initiation of prenatal care (up to $12^{\text {th }}$ gestational week or not), and the structure of prenatal services, according to payment source (public versus private).

We also described the procedures performed and orientation received during the prenatal visits. The following recommended routine procedures and tests were considered, as recorded on the prenatal card: fasting blood glucose, urinalysis, serology for syphilis (Venereal Disease Research Laboratory VDRL), serology for the human immunodeficiency virus (HIV), and ultrasound (USG). Educational practices included whether the teenage mothers had received information on labor, risk signs in pregnancy, physical activities to facilitate delivery, breastfeeding, and orientation/referral to a specific maternity hospital, as reported by the mothers themselves.

All the above-mentioned variables were analyzed according to the mother's self-reported 
skin color (white, black, mixed - brown skin, in Brazil) and economic class, according to the ABEP criterion(A/B, C, or D/E). ${ }^{14}$ Categories "A and B" and " $\mathrm{D}$ and $\mathrm{E}$ " were grouped due to the low numbers of women classified as A and E. The analysis excluded Asian-descendant (1.0\%) and indigenous $(0.7 \%)$ women due to their low proportions in the study population.

Finally, we used an indicator for minimum adequacy of prenatal care, based on several criteria for adequate care: start of prenatal care prior to the $12^{\text {th }}$ gestational week (as recommended by the "Stork Network"), 15 adequate number of prenatal visits (minimum of six, adjusted for gestational ageat delivery), recording, on the prenatal card, of at least one of the recommended prenatal tests (blood glucose, urinalysis, serology for syphilis, serology for HIV, and ultrasound), and having received orientation/referral to a specific maternity hospital for delivery. All the details on elaboration of the indicator have been published previously. ${ }^{1}$ Teenage mothers who had not attended any prenatalvisit were excluded from the sample (1.5\%), as were those who did not show a prenatal care at hospital admission for delivery $(26.20 \%)$

A descriptive analysis focused on maternal characteristics and prenatal care according to the variables "maternal skin color" and" economic class". Chi-square test $\left(\chi^{2}\right)$ was used to verify differences between proportions, with $95 \%$ confidence interval (CI95\%)

Univariate and multivariate logistic regression were used to determine which maternal characteristics and characteristics of care were associated with adequacy of prenatal care. The multivariate analysis included all the significant variables $(p<5 \%)$ from the univariate analysis. The complex sampling design was considered in the statistical analysis. Data weighting was calculated by the inverse likelihood of including each postpartum woman in the sample. A calibration procedure was used in each selection stratum to guarantee that the distribution of postpartum women was similar to that observed in the population sampled in 2011.14

All the analyses used the Statistical Package for the Social Sciences (SPSS), version 17. The study was approved by the Institutional Review Board of the National School of Public Health, Oswaldo Cruz Foundation (case review 92/2010). All proper steps were taken to ensure the information's privacy and confidentiality. Before each interview, digital consent was obtained after the participant read the free and informed consent form.

\section{Results}

After exclusion of women who had not attended any prenatal care, had not shown a prenatal card at the time of admission for childbirth, and who selfreported as Asian-descendant or indigenous, there were a total of 3,317 postpartum teenage mothers.

Distribution by major geographic region showed a higher proportion of low-income teenage mothers (economic classes $\mathrm{D} / \mathrm{E}$ ) and those with black or mixed skin color in the North and Northeast of Brazil (Figure 1). These two regions also showed the highest percentage of teenage puerperas amongst all the age brackets(Figure 2).

Teenage mothers from economic classes $\mathrm{D} / \mathrm{E}$ had the highest proportion of teenagers under 15 years of age, with inadequate schooling for age, who were already living with a companion or husband, and with a history of previous children. The situation of these mothers is also worse in regards of prenatal, having had less prenatal visits and the highest proportion of late initiation of prenatal care, besides having been treated almost exclusively in the public system (Table 1).

Inequality was also evident in relation to the mother's skin color (Table 1), with a gradient in the proportions. Darker maternal skin color was associated higher proportion of inadequate schooling for age, fewer prenatal visits, and later initiation of prenatal care. No fewer than $97 \%$ of black teenage mothers were treated in the public system.

As for procedures and educational practices during prenatal care, lower maternal economic class was associated with lower rates of testing for blood glucose, urinalysis, ultrasound, and serology for syphilis and HIV. In general, testing for syphilis (VDRL) was the most frequently performed procedure, even more common than for HIV $(85.5 \%$ and $74.8 \%$, respectively). Lower-income teenage mothers also received less orientation/referral to a specific maternity hospital for giving birth (Table 2).

As for skin color, black teenage mothers had lower rates of ultrasound and HIV serology and received less orientation on initial signs of labor. Teenage mothers as a whole received very little orientation during prenatal visits, especially information on the beginning of labor (only 43.7\%)(Table 2).

Multivariate analysis (Table 3) showed that only $15.6 \%$ of Brazilian teenage mothers received adequate prenatal care, according to minimum procedures recommended by the Ministry of Health. 15 After adjustments, the analysis showed lower rates of adequate prenatal care among teenage 
Characteristics of pregnant teenagers by major geographic region of residence, economic class, and skin color. Brazil, 2011-2012.

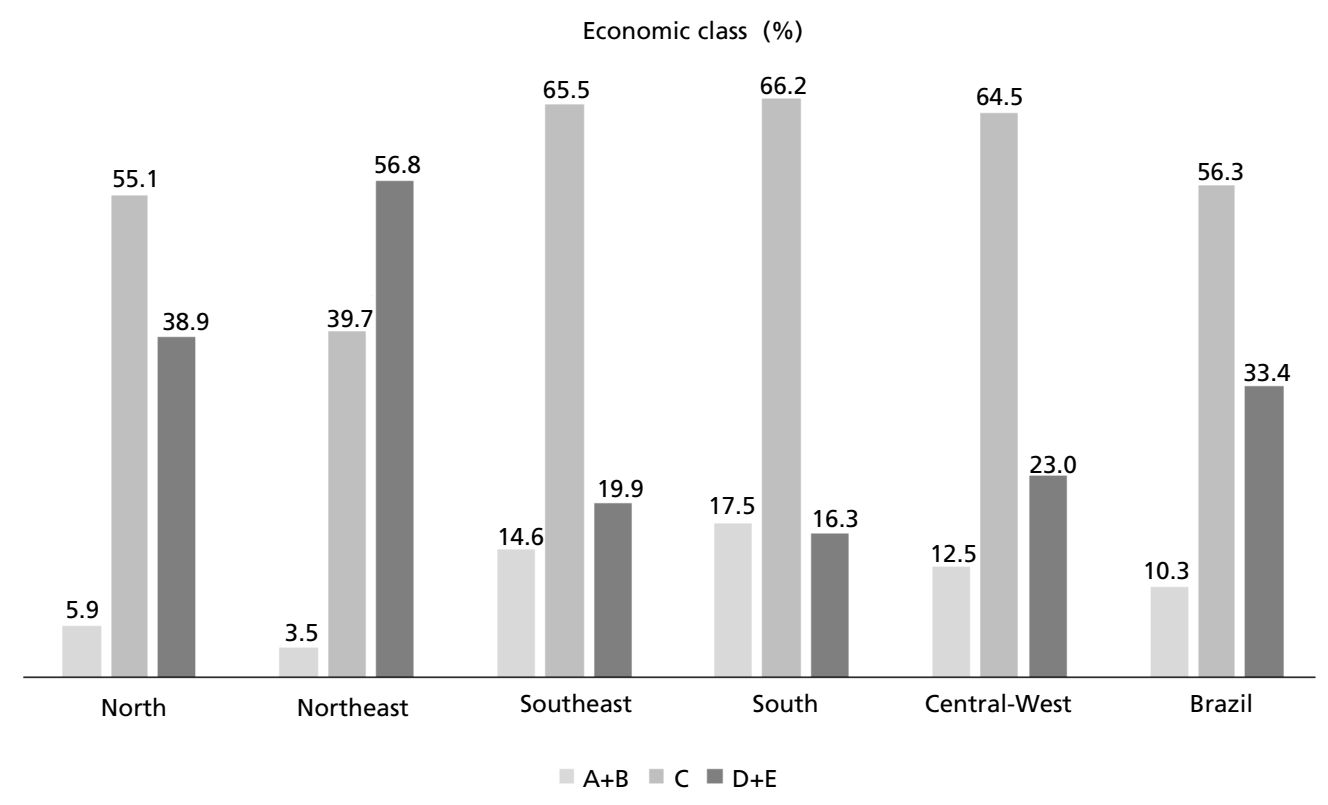

Skin color (\%)

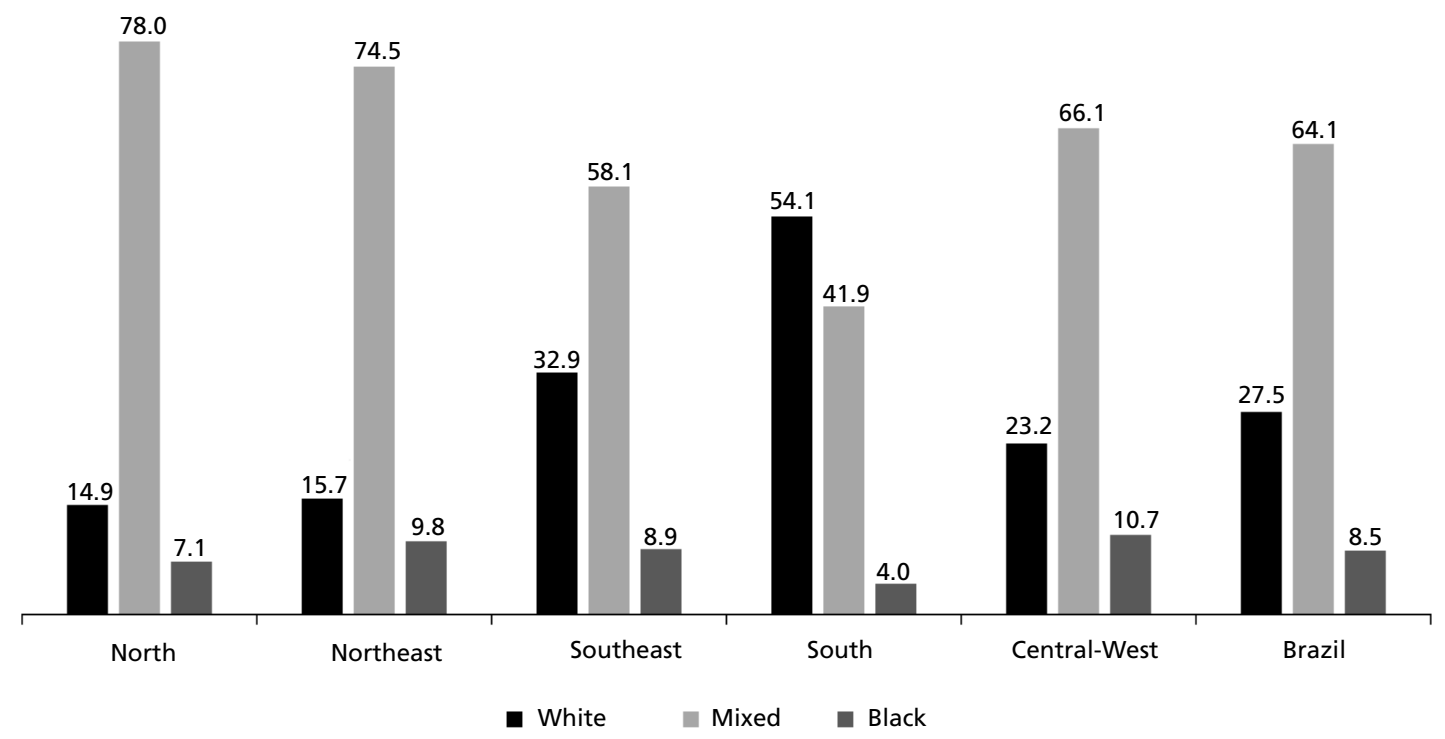

Mixed = brown skin, in Brazil 
Teenage pregnancies as a proportion of all pregnancies according to major geographic region of residence. Brazil, 2011-2012.

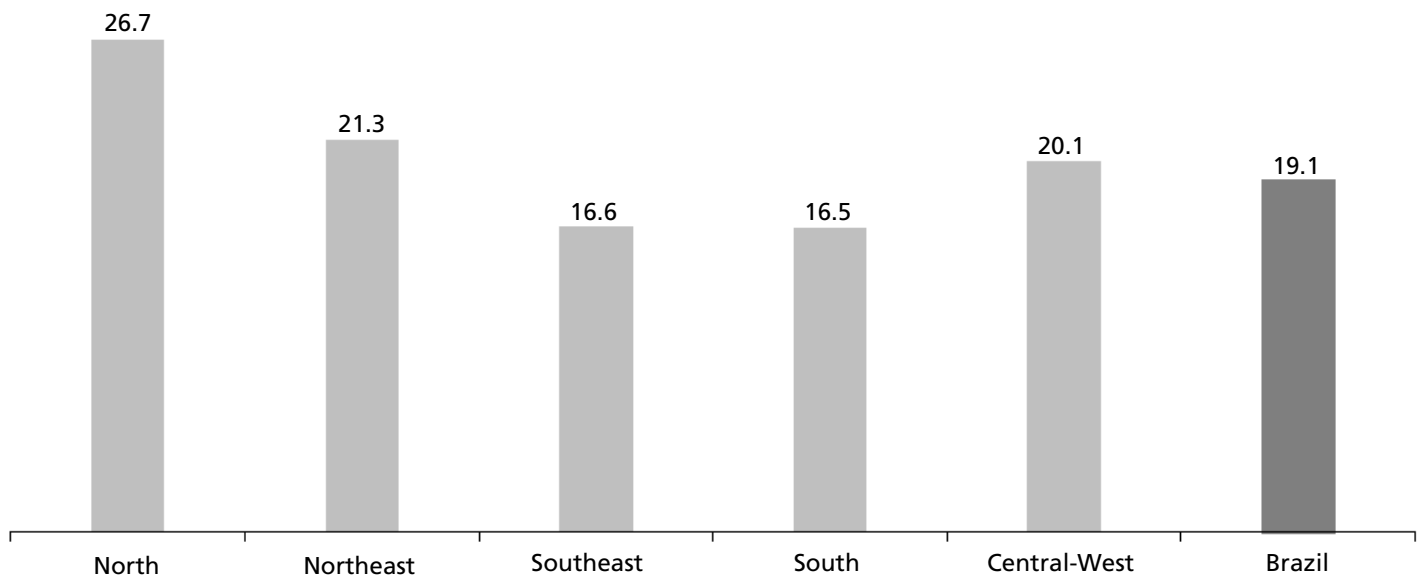

mothers with inadequate schooling for age, belonging to economic classes $\mathrm{D} / \mathrm{E}$, and with one or more previous children. Black teenage mothers showed higher odds of inadequate prenatal care when compared to their white counterparts $(\mathrm{OR}=$ $1.80 ; \mathrm{CI} 95 \%=1.07-3.03)$.

\section{Discussion}

The current study identified major inequalities in prenatal care for pregnant teenagers in Brazil, with disadvantages related to skin color and economic class. The inequalities included higher rates of inadequate prenatal care among poorer teenagers with inadequate schooling for age, and who had given birth previously.

Classes D/E included higher proportions of younger, married, and multiparous teenage mothers and those with inadequate schooling for age, with fewer prenatal visits, and who had started prenatal care later. Skin color also showed some associations, with a higher proportion of black and mixed teenage mothers showing inadequate schooling for age, while there were proportionally more white teenage mothers with six or more prenatal visits and early initiation of care. There were also observable differences in the type of service used for prenatal care, with nearly all of the poor and black teenage mothers receiving care in the public healthcare system (93.9\%).

Economic and racial disadvantage was also evident in the distribution across regions of Brazil, with a higher proportion of poor and black or mixed- teenage mothers in the North and Northeast. This difference reinforces the country's inequalities, since these geographic regions have the lowest Human Development Indexes (HDI) 16 and the highest maternal mortality 17 and neonatal mortality rates. 18 These regions also display the highest proportion of pregnant teenagers that started their prenatal care late and that had fewer visits and routine procedures during the pregnancy. ${ }^{1}$

Other Brazilian studies have also shown problems with early uptake of poor black and mixed pregnant teenagers, 19,20 as well as with completing the recommended number of prenatal visits according to the calendar proposed by the Ministry of Health. 1

The reduction of barriers to diagnosis of pregnancy, early initiation of prenatal care, and more prenatal visits would provide more opportunities for health promotion for pregnant teenagers. However, the most relevant discussion concerns the quality of care actually provided, related to inequalities experienced by poor black and mixed adolescent women in Brazil.

According to Kalckmannk et al.,21 the center of the harsh social inequality in the use of available resources lies in social hierarchy, with health inequalities between whites and blacks, where the latter occupy lower positions and thus unequal experiences in birth, life, illness, and death.

The precarious organization of health services and difficulties in early uptake of pregnant teenagers are evidenced by the later initiation of prenatal care by poor black and mixed teenagers. Early initiation 
Table 1

\begin{tabular}{|c|c|c|c|c|c|c|c|c|c|c|}
\hline \multirow[t]{2}{*}{ Variables } & \multicolumn{3}{|c|}{ Economic class $(\%)$} & \multirow[t]{2}{*}{$p$} & \multicolumn{3}{|c|}{ Skin color $(\%)$} & \multirow[t]{2}{*}{$p$} & \multicolumn{2}{|c|}{ Total $(\mathrm{N}=3,317)$} \\
\hline & $A+B$ & $\mathrm{C}$ & $D+E$ & & White & Mixed & Black & & $\mathrm{n}$ & $\%$ \\
\hline Age (years) & & & & 0.001 & & & & 0.069 & & \\
\hline 10 to 14 & 2.7 & 4.1 & 8.5 & & 4.1 & 5.6 & 8.5 & & 181 & 5.5 \\
\hline 15 to 19 & 97.9 & 95.9 & 91.5 & & 95.9 & 94.4 & 91.5 & & 3,136 & 94.5 \\
\hline Schooling & & & & $<0.001$ & & & & $<0.001$ & & \\
\hline Adequate for age & 67.2 & 46.7 & 27.3 & & 49.9 & 40.3 & 33.9 & & 1,398 & 42.2 \\
\hline Inadequate for age & 32.8 & 53.3 & 72.7 & & 50.1 & 59.7 & 66.1 & & 1,903 & 57.4 \\
\hline Conjugal status & & & & $<0.001$ & & & & 0.956 & & \\
\hline Living with companion & 62.1 & 65.8 & 76.3 & & 68.8 & 69.1 & 67.9 & & 2,283 & 68.8 \\
\hline Without companion & 37.9 & 34.2 & 23.7 & & 31.2 & 30.9 & 32.1 & & 1,031 & 31.1 \\
\hline Parity & & & & $<0.001$ & & & & 0.532 & & \\
\hline Nulliparous & 89.9 & 84.7 & 76.1 & & 84.3 & 81.9 & 80.3 & & 2,734 & 82.4 \\
\hline 1 previous child & 9.2 & 13.6 & 20.2 & & 14.0 & 15.5 & 18.0 & & 507 & 15.3 \\
\hline$\geq 2$ previous children & 0.8 & 1.7 & 3.7 & & 1.8 & 2.6 & 1.7 & & 75 & 2.3 \\
\hline Numberof prenatal visits & & & & 0.001 & & & & 0.001 & & \\
\hline 1 to 3 & 9.1 & 12.4 & 21.1 & & 13.4 & 14.7 & 21.3 & & 495 & 14.9 \\
\hline 4 to 5 & 25.0 & 23.5 & 26.8 & & 19.0 & 26.4 & 29.9 & & 818 & 24.7 \\
\hline$\geq 6$ & 65.9 & 64.1 & 52.1 & & 67.6 & 58.8 & 48.8 & & 2,002 & 60.4 \\
\hline Early initiation of prenatal care & & & & 0.003 & & & & 0.004 & & \\
\hline Yes & 46.8 & 46.3 & 36.0 & & 46.2 & 42.8 & 31.8 & & 1,410 & 42.5 \\
\hline No & 53.2 & 53.7 & 64.0 & & 53.8 & 57.2 & 68.2 & & 1,886 & 56.9 \\
\hline Type of prenatal service & & & & $<0.001$ & & & & $<0.001$ & & \\
\hline Public & 84.8 & 93.4 & 97.6 & & 90.0 & 95.1 & 97.6 & & 3,103 & 93.6 \\
\hline Private & 15.2 & 6.6 & 2.4 & & 10.0 & 4.9 & 2.4 & & 201 & 6.1 \\
\hline
\end{tabular}

Mixed = brown skin, in Brazil; Chi-square test.

Table 2

Procedures and educational practices during prenatal care for pregnant teenagers according to economic class and skin color, Brazil, 20112012.

\begin{tabular}{|c|c|c|c|c|c|c|c|c|c|c|}
\hline \multirow[t]{2}{*}{ Variables } & \multicolumn{3}{|c|}{ Economic class (\%) } & \multirow[t]{2}{*}{$p$} & \multicolumn{3}{|c|}{ Skin color (\%) } & \multirow[t]{2}{*}{$p$} & \multicolumn{2}{|c|}{ Total $(\mathrm{N}=3,317)$} \\
\hline & $A+B$ & $\mathrm{C}$ & $D+E$ & & White & Mixed & Black & & $\mathrm{n}$ & $\%$ \\
\hline \multicolumn{11}{|l|}{ Tests* } \\
\hline Blood glucose & & & & 0.050 & & & & 0.051 & & \\
\hline Yes & 85.7 & 82.5 & 77.6 & & 84.3 & 80.4 & 75.3 & & 2,688 & 81.0 \\
\hline No & 14.3 & 17.5 & 22.4 & & 15.7 & 19.6 & 24.7 & & 629 & 19.0 \\
\hline Urinalysis & & & & 0.006 & & & & 0.134 & & \\
\hline Yes & 87.5 & 84.6 & 78.6 & & 85.4 & 82.3 & 78.5 & & 2,748 & 82.2 \\
\hline No & 12.5 & 15.4 & 21.4 & & 14.6 & 17.7 & 21.5 & & 569 & 17.2 \\
\hline Ultrasound & & & & $<0.001$ & & & & 0.041 & & \\
\hline Yes & 92.0 & 86.4 & 73.3 & & 86.6 & 81.0 & 79.7 & & 2,734 & 82.4 \\
\hline No & 8.0 & 13.6 & 26.7 & & 13.4 & 19.0 & 20.3 & & 583 & 17.6 \\
\hline VDRL (syphilis) & & & & $<0.001$ & & & & 0.106 & & \\
\hline Yes & 92.6 & 87.1 & 80.7 & & 87.6 & 85.2 & 80.1 & & 2,835 & 85.5 \\
\hline No & 7.4 & 12.9 & 19.3 & & 12.4 & 14.8 & 19.9 & & 482 & 14.5 \\
\hline HIV & & & & $<0.001$ & & & & 0.001 & & \\
\hline Yes & 90.0 & 79.3 & 62.5 & & 81.6 & 72.4 & 70.3 & & 2,480 & 74.8 \\
\hline No & 10.0 & 20.7 & 37.5 & & 18.4 & 27.6 & 29.7 & & 837 & 25.2 \\
\hline
\end{tabular}

* information on prenatal card ; Mixed = brown skin, in Brazil; Chi-square test. 
Procedures and educational practices during prenatal care for pregnant teenagers according to economic class and skin color, Brazil, 20112012.

\begin{tabular}{|c|c|c|c|c|c|c|c|c|c|c|}
\hline \multirow[t]{2}{*}{ Variables } & \multicolumn{3}{|c|}{ Economic class $(\%)$} & \multirow[t]{2}{*}{$p$} & \multicolumn{3}{|c|}{ Skin color $(\%)$} & \multirow[t]{2}{*}{$p$} & \multicolumn{2}{|c|}{ Total $(\mathrm{N}=3,317)$} \\
\hline & $A+B$ & $\mathrm{C}$ & $D+E$ & & White & Mixed & Black & & $\mathrm{n}$ & $\%$ \\
\hline \multicolumn{11}{|l|}{ Information/Orientation } \\
\hline Start of labor & & & & 0.296 & & & & 0.048 & & \\
\hline Yes & 47.2 & 44.5 & 41.1 & & 48.4 & 42.4 & 41.3 & & 1,449 & 43.7 \\
\hline No & 52.8 & 55.5 & 58.9 & & 51.6 & 57.6 & 58.7 & & 1,850 & 55.8 \\
\hline Risk signs & & & & 0.481 & & & & 0.185 & & \\
\hline Yes & 58.7 & 55.5 & 52.7 & & 58.4 & 53.8 & 52.3 & & 1,812 & 54.6 \\
\hline No & 41.3 & 44.5 & 47.3 & & 41.6 & 46.2 & 47.7 & & 1,485 & 44.8 \\
\hline Physical activity to facilitate delivery & & & & 0.935 & & & & 0.453 & & \\
\hline Yes & 40.1 & 39.5 & 40.5 & & 37.9 & 41.1 & 40.5 & & 1,325 & 39.9 \\
\hline No & 59.9 & 60.5 & 59.5 & & 62.1 & 58.9 & 59.5 & & 1,976 & 59.6 \\
\hline Breastfeeding in the first hour & & & & 0.403 & & & & 0.616 & & \\
\hline Yes & 55.9 & 59.6 & 62.5 & & 58.6 & 61.1 & 59.4 & & 1,989 & 60.0 \\
\hline No & 44.1 & 40.4 & 37.5 & & 41.4 & 38.9 & 40.6 & & 1,312 & 39.6 \\
\hline \multicolumn{4}{|c|}{ Orientation/referral to specific maternity hospital } & 0.007 & & & & 0.240 & & \\
\hline Yes & 56.8 & 55.1 & 45.3 & & 55.7 & 51.0 & 50.3 & & 1,729 & 52.1 \\
\hline No & 43.2 & 44.9 & 54.7 & & 44.3 & 49.0 & 49.7 & & 1,582 & 47.7 \\
\hline
\end{tabular}

* information on prenatal card ; Mixed = brown skin, in Brazil; Chi-square test.

Table 3

Factors associated with inadequate prenatal care in pregnant teenagers, Brazil, 2011-2012.

\begin{tabular}{|c|c|c|c|c|c|c|c|c|}
\hline \multirow[t]{2}{*}{ Variables } & \multicolumn{8}{|c|}{ Adequacy of prenatal care** } \\
\hline & Adequate(\%) & Inadequate(\%) & Crude OR & $\mathrm{Cl} 95 \%$ & $p$ & Adjusted OR* & $\mathrm{Cl} 95 \%$ & $p$ \\
\hline \multicolumn{5}{|l|}{ Age (years) } & 0.287 & & & - \\
\hline 10 to 14 & 4.2 & 5.7 & 1.39 & $0.76-2.58$ & & - & - & \\
\hline 15 to 19 & 95.8 & 94.3 & 1 & - & & - & - & \\
\hline \multicolumn{5}{|l|}{ Schooling } & $<0.001$ & & & 0.012 \\
\hline Adequate for age & 55.4 & 39.9 & 1 & - & & 1 & - & \\
\hline Inadequate for age & 44.6 & 60.1 & 1.87 & $1.40-2.48$ & & 1.48 & $1.09-2.02$ & \\
\hline \multicolumn{5}{|l|}{ Skin color } & 0.005 & & & 0.079 \\
\hline White & 34.2 & 26.2 & 1 & - & & 1 & - & \\
\hline Mixed & 60.4 & 64.7 & 1.40 & $1.06-1.84$ & & 1.23 & $0.92-1.65$ & \\
\hline Black & 5.4 & 9.0 & 2.20 & $1.32-3.65$ & & 1.80 & $1.07-3.03$ & \\
\hline \multicolumn{5}{|l|}{ Economic class } & $<0.001$ & & & $<0.001$ \\
\hline$A+B$ & 15.1 & 9.4 & 1 & - & & 1 & - & \\
\hline $\mathrm{C}$ & 64.9 & 54.7 & 1.35 & $0.93-1.97$ & & 1.21 & $0.82-1.77$ & \\
\hline$D+E$ & 20.0 & 35.9 & 2.89 & $1.75-4.76$ & & 2.19 & $1.30-3.71$ & \\
\hline \multicolumn{5}{|l|}{ Conjugal status } & 0.349 & & & - \\
\hline Living with companion & 71.2 & 68.5 & 1 & - & & - & - & \\
\hline Without companion & 28.8 & 31.5 & 1.14 & $0.86-1.51$ & & - & - & \\
\hline \multicolumn{5}{|l|}{ Parity } & $<0.001$ & & & 0.024 \\
\hline Nulliparous & 89.4 & 81.1 & 1 & - & & 1 & - & \\
\hline 1 previous child & 9.7 & 16.3 & 1.86 & $1.30-2.67$ & & 1.53 & $1.04-2.27$ & \\
\hline$\geq 2$ previous children & 1.0 & 2.5 & 3.19 & $1.11-9.14$ & & 2.35 & $0.83-6.66$ & \\
\hline \multicolumn{5}{|c|}{ Source of payment for prenatal care } & 0.541 & & & - \\
\hline Public & 94.6 & 93.8 & 1 & - & & - & - & \\
\hline Private & 5.4 & 6.2 & 1.14 & $0.74-1.77$ & & - & - & \\
\hline Total & 15.6 & 84.4 & & & & & & \\
\hline
\end{tabular}

$\mathrm{OR}==$ odds ratio; *Variables adjusted for each other; ** Adequacy of prenatal care: first visit up to 12 th gestational week; adequate number of visits for gestational at the time of delivery, considering the minimum recommendation of six visits; at least one of the routine prenatal tests; orientation on the maternity hospital for childbirth; Mixed = brown skin, in Brazil. 
of prenatal care allows anticipating the identification of risks and preventing complications, detecting and treating diseases such as gestational diabetes and pregnancy-induced hypertension, diagnosing and treating cases of urinary tract infection and its complications, and detection of HIV and syphilis in the pregnancy, preventing congenital syphilis, for example. 22,23

The study found that approximately one-fifth of black teenage mothers belonging to economic classes D/E had not been tested for syphilis (VDRL). Mixed teenage mothers showed the same pattern, but slightly attenuated. This scenario was repeated with ultrasound and HIV serology. The low proportion of routine tests and orientation during prenatal care reveal the precariousness of the care provided and its inability to preserve the health of teenage mothers and their infants, thus missing an opportunity to orient mothers on good practices in labor and childbirth, which are extremely relevant for promoting vaginal delivery and encouraging breastfeeding. 8,22

The disadvantages are also evident at the end of pregnancy, since poor black and mixed teenagers are the ones that report receiving less orientation on referral to a specific maternity hospital for delivery, which is essential to avoid the "pilgrimage" from one hospital to another when they enter labor. 1 Health services that should be compensating for social disadvantage are thus adding insult to injury by reproducing inequalities, demonstrating the system's inefficiency and highlighting a so-called "inverse equality", in which those most in need of care are the ones who least receive it.2

Although Brazil boasts broad prenatal coverage8, few teenagers in the Birth in Brazil survey had received adequate care during pregnancy. Inadequate prenatal care was more common in poor black teenagers, those with low schooling for age, and multiparous teenagers, clearly revealing the situation of social disadvantage for these women, as well as the differentiated perception of quality of care offered to them by health services.

A survey of pregnant teenagers in the United States found a differential effect of skin color on prenatal care, with white teenagers beginning prenatal care earlier. 5 A Brazilian ecological study also showed an important correlation, with fewer prenatal visits reported by black women and those with low schooling. ${ }^{24}$

Psychosocial barriers can also hinder teenagers' access to health services. Some of these barriers are represented by fear of verbal confirmation of the pregnancy by the attending health professional in the presence of the young woman's accompany person. 25

In this sense, the relationship of trust between health professionals and the pregnant teenager provide a great opportunity for their access to prenatal services. Such attitudes are also essential for avoiding a subsequent unintended pregnancy. It has been shown that dissatisfaction with the pregnancy is significantly greater in teenagers $(31.8 \%)$ than in women aged twenty years or older $(28.6 \%),{ }^{26}$ and that it is even associated with the group's unfavorable perception in relation to the care provided by health services. 25 However, pregnancy can be successful in teenager mothers as long as they receive adequate prenatal care, capable of reducing typical disadvantages of young maternal age, while improving perinatal outcomes. 12

Teenage pregnancy is known to be an aggravating factor for school dropout by many teenage girls, and for more difficulty competing in the work market, with a possible negative impact on economic betterment in these young women, 12 as well as on the teenagers' perception of their health status, their ability to understand orientation received during prenatal visits, their use of health services, and their adherence to procedures recommended by health professionals during prenatal care, 27 thus converging in a situation of social disadvantage.

Chiavarini et al.28 studied the impact of sociodemographic determinants on prenatal care in an administrative region of Italy and found a higher proportion of late initiation of care and fewer prenatal visits in women with low schooling.

These findings reinforce the protective role of education on teenagers' health, since schooling can also influence their perception of their health problems, their capacity to understand the information received, their access to (and use of) health services, and their adherence to the procedures recommended by health professionals during the prenatal visit.

The increase in the number of children, largely determined by early initiation into childbearing, is another dimension of this same phenomenon that reinforces the social exclusion of these young women. ${ }^{4}$ In the current study, the harms identified by teenage mothers with previous pregnancies were similar to the results of other studies that also reported higher odds of inadequate prenatal care in this group. These teenagers may also have less available time due to the overload from raising children, or they may feel that they already have sufficient experience from their previous pregnancies. 9,7

The results reflect Brazil's historically constructed and persistent discrimination, whereby poor black women receive the worst care and are 
marginalized by society. Thus, to be born black and poor and to conceive during adolescence are strong risk factors for various negative maternal and perinatal outcomes. A study found similar results in women of all age brackets, where black and mixed women (compared to white women) generally presented worse prenatal and childbirth indicators. 29

Improvement in the quality of healthcare means the elimination of racial inequalities, and such components are inseparable. According to the abovementioned authors, 29 to identify and fight practices that potentially generate inequalities, educational measures are also needed for professionals in the health services, which are certainly a key component in this context, even though the principal determinants of these inequalities lie in society and cannot be corrected by isolated efforts.

The obtained data emphasize the need to implement public policies on sexual and reproductive health in adolescence, especially early uptake of pregnant teenagers, facilitating their access to prenatal services and diagnostic tests, as well as training health professionals in this care. The institutionalization of effective measures with a focus on obstetric planning and education, targeted to this age group, especially socioeconomically underprivileged

\section{References}

1. Domingues RMSM, Viellas EF, Dias MAB, Torres JA, Theme-Filha MM, Gama SGN, Carmo Leal M. Adequação da assistência pré-natal segundo as características maternas no Brasil. Rev Panam Salud Publica. 2015; 37 (3): 140-7.

2. Victora CG, Matijasevich A, Silveira MF, Santos IS, Barros AJD, Barros FC. Socio-economic and ethnic group inequities in antenatal care quality in the public and private sector in Brazil. Health Policy Plan 2010; 25: 253-61.

3. Silveira MF, Barros AJD, Santos IS, Matijasevich A, Victora CG. Socioeconomic differentials in performing urinalysis during prenatal care. Rev Saúde Pública. 2008; 42 (3): 389-95.

4. Leal MC, Gama SGN, Cunha CB. Desigualdades raciais, sociodemográficas e na assistência ao pré-natal e ao parto, 1999-2001. Rev Saúde Pública. 2005; 39: 100-7.

5. Hueston WJ, Geesey ME, Diaz V. Prenatal care initiation among pregnant teens in the United States: an analysis over 25 years. J Adolesc Health. 2008; 42 (3): 243-8.

6. Magadi MA, Agwanda AO, Obare FO: A comparative analysis of the use of maternal health services between teenagers and older mothers in subSaharan Africa: evidence from Demographic and Health Surveys (DHS). Soc Sci Med. 2007; 64: 1311-25.

7. Fonseca SC, Kale PL, Silva KS. Pré-natal em mulheres usuárias do Sistema Único de Saúde em duas maternidades no Estado do Rio de Janeiro, Brasil: a cor importa? RevBras Saúde Matern Infant. 2015; 15 (2): 209-17. women, is one of the alternatives for changing this reality. Development strategies for society's excluded sectors should help guide improvement in the quality of care and thus allow greater visibility and discussion of the issue.

It is expected that the study's results can help back policies to retain teenagers in the school system and inclusion in health services, whose role should be to minimize the inequalities discussed here. In the case of pregnant teenagers, the aim should be highquality prenatal care with no discrimination on the basis of geographic region, race, or economic status. The study has some limitations. The analysis only included teenagers who brought prenatal cards to the maternity hospital when they were admitted for childbirth. However, no statistically significant differences were found between those with and without prenatal cards. In addition, self-classified skin color entails some degree of subjectivity and depends on factors such as individual's social insertion.

On the other hand, the findings' validity is backed by the study's use of a national sample representing all regions of Brazil.

8. Viellas EF, Domingues RMSM, Dias MAB, Gama SGN, Theme Filha MM, Costa JV, Bastos MH, Carmo Leal M. Assistência pré-natal no Brasil. Cad Saúde Pública. 2014; 30 (Supl. 1): S85-S100.

9. Bernardes ACF, Silva RA, Coimbra LC, Alves MTSSB, Queiroz RCS, Batista RFL, Bettiol H, Barbieri MA, Silva AAM. Inadequate prenatal care utilization and associated factors in São Luís, Brazil. BMC Pregnancy Childbirth. 2014; 14: 266.

10. Santos LAV, Lara MO, Lima RCR, Rocha AF, Rocha EM, Glória JCR, Ribeiro GC. História gestacional e características da assistência pré-natal de puérperas adolescentes e adultas em uma maternidade do interior de Minas Gerais, Brasil. Ciênc Saúde Coletiva. 2018; 23 (2): 617-25.

11. Bassani DG, Surkan PJ, Olinto MTA. Inadequate use of prenatal services among Brazilian women: the role of maternal characteristics. Int Perspect Sex Reprod Health. 2009; 35:15-20.

12. Gama SGN, Szwarcwald CL, Sabroza AR, Branco VC, Leal MC. Fatores associados à as-sistência pré-natal precária em uma amostra de puérperas adolescentes em maternidades do Município do Rio de Janeiro, 1999-2000. Cad Saúde Pública. 2004; 20 (Supl. 1): S101-11.

13. Vasconcellos MTL, Silva PLN, Esteves- Pereira AP, Schilithz AOC, Souza Junior PRB, Szwarcwald CL. Sampling design for the Birth in Brazil: National Survey into Labour and Birth. Cad Saúde Pública. 2014; 30 (Supl. 1): $S 49-58$ 
14. Carmo Leal M, Silva AA, Dias MA, Gama SG, Rattner D, Moreira ME, Filha MM, Domingues RM, Pereira AP, Torres JA, Bittencourt SD, D'orsiE, Cunha AJ, Leite AJ, Cavalcante RS, Lansky S, Diniz CS, Szwarcwald CL. Birth in Brazil: national survey into labour and birth. Reprod Health. 2012; 9: 15.

15. Brasil. Ministério da Saúde. Portaria 1 459/2011. Disponível em http://bvsms.saude.gov.br/bvs/ saudelegis/ gm/2011/prt1459_24_06_2011.html Acessado em abril de 2017.

16. Brasil. PNUD (Programa das Nações Unidas para o Desenvolvimento). Relatório Anual 2016 Desenvolvimento Humano nas Macrorregiões Brasileiras. 2016 [Internet]. Brasília: Programa das Nações Unidas para o Desenvolvimento; 2016. Disponível em: http://www.br. undp.org/content/brazil/pt/home/library/idh1/macroregioes-brasileiras.html.

17. Szwarcwald CL, Escalante JJC, Rabello Neto DL, Souza Junior PRB, Victora CG. Estimação da razão de mortalidade materna no Brasil, 2008-2011. Cad Saúde Pública. 2014; 30 (Supl. 1): S71-83.

18. Lansky S, Friche AAL, Silva AAM, Campos D, Bittencourt DAS, Carvalho ML, et al. Pesquisa Nascer no Brasil: perfil da mortalidade neonatal e avaliação da assistência à gestante e ao recém-nascido. Cad Saúde Pública. 2014; 39 (Supl. 1): S192-207.

19. Chrestani MAD, Santos IS, Cesar JA, Winckler LS, Gonçalves TS, Neumann NA. Assistência à gestação e ao parto: resultado de dois estudos transversais em áreas pobres das regiões Norte e Nordeste do Brasil. Cad Saúde Pública. 2008; 24: 1609-18

20. Andreucci CB, Cecatti, JG. Desempenho de indicadores de processo do Programa de Humanização do Pré-Natal e Nascimento no Brasil: uma revisão sistemática. Cad Saúde Pública. 2011; 27: 1053-64.

21. Kalckmann S; Santos CG; Batista LE, Cruz MV. Racismo Institucional: um desafio para a equidade no SUS. Saúde Soc. $2007 ; 16: 146-155$.

Received on October 27, 2017

Final version presented on May 24, 2018

Approved on September 21, 2018
22. Polgliane RBS, Leal MC, Amorim MHC, Zandonade E, Santos Neto ET. Adequação do processo de assistência prénatal segundo critérios do Programa de Humanização do Pré-natal e Nascimento e da Organização Mundial de Saúde. Ciênc Saúde Coletiva. 2014; 19 (7): 1999-2010.

23. Anversa ETR, Bastos GAN, Nunes LN, Pizzol TSD. Qualidade do processo da assistência pré-natal: unidades básicas de saúde e unidades de Estratégia Saúde da Família em município no Sul do Brasil. Cad Saúde Pública. 2012; 28 (4): 789-800

24. Predebon KM, Mathias TA, Aidar T, Rodrigues AL. Desigualdade sócio-espacial expressa por indicadores do Sistema de Informações sobre Nascidos Vivos (SINASC). Cad Saúde Pública. 2010; 26 (8): 1583-94.

25. Shaw D. Access to sexual and reproductive health for young people: Bridging the disconnect between rights and reality.Int J Gynaecol Obstet.2009; 106 (2): 132-6.

26. Theme-Filha MM, Baldisserotto ML, Fraga ACSA, Ayres S, Gama SGNG e Leal MC. Factors associated with unintended pregnancy in Brazil: cross-sectional results from the Birth in Brazil National Survey, 2011/2012. Reprod Health. 2016; 13 (Suppl. 3): 118.

27. Viellas EF, Gama SGN, Theme Filha MM, Leal MC. Gravidez recorrente na adolescência e os desfechos negativos no recém-nascido: um estudo no Município do Rio de Janeiro. Rev Bras Epidemiol. 2012; 15: 443-54.

28. Chiavarini M, Lanari D, Minelli L, Salmasi L. Socio-demographic determinants and access to prenatal care in Italy. BMC Health Serv Res. 2014; 14:174.

29. Carmo Leal M, Gama SGN, Pereira APE, Pacheco VE, Carmo CN, Santos RV. A cor da dor: iniquidades raciais na atenção pré-natal e ao parto no Brasil. Cad Saúde Pública. 2017; 33 (Supl. 1): 1-17 